\title{
Inflammatory mediators reduce surface PrPc on human BMVEC resulting in decreased barrier integrity
}

\author{
Bezawit W. Megra' Eliseo A. Eugenin ${ }^{2,3}$ - Joan W. Berman ${ }^{1,4}$
}

Received: 5 November 2017 / Revised: 3 May 2018 / Accepted: 5 May 2018 / Published online: 29 June 2018

(c) United States \& Canadian Academy of Pathology 2018

\begin{abstract}
The cellular prion protein $\left(\mathrm{PrP}^{\mathrm{c}}\right)$ is a surface adhesion molecule expressed at junctions of various cell types including brain microvascular endothelial cells (BMVEC) that are important components of the blood-brain barrier (BBB). $\operatorname{PrP}^{\mathrm{c}}$ is involved in several physiological processes including regulation of epithelial cell barrier function and monocyte migration across BMVEC. BBB dysfunction and disruption are significant events in central nervous system (CNS) inflammatory processes including HIV neuropathogenesis. Tumor necrosis factor (TNF)- $\alpha$ and vascular endothelial growth factor (VEGF) are two inflammatory factors that have been implicated in the processes that affect BBB integrity. To examine the effect of inflammation on $\operatorname{PrP}^{\mathrm{c}}$ expression in BMVEC, we used these mediators and found that TNF- $\alpha$ and VEGF decrease surface $\mathrm{PrP}^{\mathrm{c}}$ on primary human BMVEC. We also showed that these factors decrease total $\operatorname{PrP}^{\mathrm{c}}$ protein as well as mRNA, indicating that they regulate expression of this protein by de novo synthesis. To determine the effect of $\operatorname{PrP}^{\mathrm{C}}$ loss from the surface of BMVEC on barrier integrity, we used small hairpin RNAs to knockdown $\operatorname{PrP}^{\mathrm{c}}$. We found that the absence of $\operatorname{PrP}^{\mathrm{c}}$ from BMVEC causes increased permeability as determined by a fluorescein isothiocyanate (FITC)-dextran permeability assay. This suggests that cell surface $\operatorname{PrP}^{\mathrm{c}}$ is essential for endothelial monolayer integrity. To determine the mechanism by which $\operatorname{PrP}^{\mathrm{c}}$ downregulation leads to increased permeability of an endothelial monolayer, we examined changes in expression and localization of tight junction proteins, occludin and claudin-5, and found that decreased $\operatorname{PrP}^{\mathrm{c}}$ leads to decreased total and membrane-associated occludin and claudin-5. We propose that an additional mechanism by which inflammatory factors affect endothelial monolayer permeability is by decreasing cell-associated $\operatorname{PrP}^{\mathrm{c}}$. This increase in permeability may have subsequent consequences that lead to CNS damage.
\end{abstract}

\section{Introduction}

The cellular prion protein $\left(\mathrm{PrP}^{\mathrm{c}}\right)$ is the non-pathogenic cellular isoform of human prion protein that is constitutively expressed in central nervous system (CNS) cells $[1,2] . \mathrm{PrP}^{\mathrm{c}}$ is an adhesion molecule and has several proposed functions

Joan W. Berman

joan.berman@einstein.yu.edu

1 Department of Pathology, Albert Einstein College of Medicine, Bronx, NY 10461, USA

2 Public Health Research Institute (PHRI), Newark, NJ 07103, USA

3 Department of Microbiology and Molecular Genetics, Rutgers New Jersey Medical School, Rutgers The State University of New Jersey, Newark, NJ 07103, USA

4 Department of Microbiology and Immunology, Albert Einstein College of Medicine, Bronx, NY 10461, USA including facilitating monocyte transmigration across endothelium and intracellular signal transduction [3-9]. It is a glycosylphosphatidylinositol-anchored glycoprotein found in membrane raft microdomains with several signaling molecules including Src-family kinases, suggesting that it might be part of a signaling complex [4, 10-13] . This protein is present in unglycosylated, monoglycosylated, and diglycosylated forms and can have $\sim 60$ different sugars attached to it, enabling it to interact with several ligands for diverse functions $[14,15]$.

In the $\mathrm{CNS}, \operatorname{PrP}^{\mathrm{c}}$ is abundantly expressed in neurons, microglia, and cells of the blood-brain barrier (BBB), including astrocytes and brain microvascular endothelial cells (BMVEC) $[1,9,16,17]$. It is present on brain endothelial cells of mouse, rat, and human origin, localized in raft/caveolae-like membrane microdomains and concentrated at intercellular junctions of cells [9]. It is hypothesized that the junctional localization of $\operatorname{PrP}^{\mathrm{c}}$ is dependent on homophilic interactions between $\operatorname{PrP}^{\mathrm{c}}$ on two adjacent 
cells [9]. The interaction of $\operatorname{PrP}^{\mathrm{c}}$ between two endothelial cells as well as between endothelial cells and monocytes was also shown to be essential for the migration of monocytes across an endothelial monolayer [9, 18].

BMVECs are a major component of the BBB. The integrity of the BBB is essential to CNS homeostasis by controlling the transmission of biochemical signals and the transmigration of leukocytes from blood into the CNS in a regulated manner [19-21]. The BBB also excludes certain soluble factors from the CNS while allowing specific nutrients to transport in and out of the brain [22, 23]. During neuroinflammation, the BBB responds by remodeling of junctional proteins in response to intracellular signaling that will result in endothelial retraction [24]. Disruption of the BBB leads to increased transmigration of leukocytes, impaired CNS homeostasis, and pathogen entry that can lead to neurologic compromise $[19,25]$.

In enterocytes, $\operatorname{PrP}^{\mathrm{c}}$ colocalizes with E-cadherin and interacts with several desmosomal proteins, suggesting that it contributes to the adhesion and barrier function of intestinal epithelial cells [26]. Studies in these cells demonstrate that the absence of this protein leads to the mislocalization of tight junction (TJ) proteins that is accompanied by increased paracellular permeability [26].

In this study, we examined the effect of tumor necrosis factor (TNF)- $\alpha$ and vascular endothelial growth factor (VEGF) on BMVEC expression of $\operatorname{PrP}^{\mathrm{c}}$ and how changes in $\operatorname{PrP}^{\mathrm{c}}$ expression altered endothelial monolayer integrity and permeability. TNF- $\alpha$ is associated with BBB disruption and barrier permeability [27-29]. It is increased in the CNS in response to various pathogens as well as in neurodegenerative diseases including Alzheimer's, Parkinson's, amyotrophic lateral sclerosis, multiple sclerosis, and HIV infection of the CNS [30-35]. TNF- $\alpha$ increases production of the cytokines IL-6, CCL2, and IL-8 from CNS cells and these dysregulate adhesion protein expression and increase leukocyte transmigration across the BBB and accumulation within the CNS [36-38]. In endothelial monolayer BBB models, TNF- $\alpha$ has been shown to cause increased permeability by activating nuclear factor (NF)- $\kappa \beta$ signaling, resulting in claudin-5, occludin, and $\mathrm{ZO}-1$ downregulation [39].

Another factor implicated in BBB breakdown is VEGF $[40,41]$. VEGF is the most potent angiogenic factor and is involved in vasculogenesis during embryonic development and vascular injury [42]. In addition to its importance in angiogenesis, it has been shown to be neuroprotective in rodent models of neurodegeneration, indicating that its role in the CNS is complex [43-45]. In the inflamed CNS, VEGF is produced by reactive astrocytes and this growth factor has been shown to contribute to loss of brain microvascular integrity by decreasing the $\mathrm{TJ}$ proteins claudin-5 and occludin [46, 47]. VEGF promotes VE- cadherin endocytosis in a $\beta$-arrestin-dependent manner as well as VE-cadherin phosphorylation, resulting in its disassembly [48, 49]. This adherens protein is essential for BBB integrity and its dysregulation by VEGF can lead to increased BBB permeability.

We used these inflammatory factors in our study to examine the regulation of $\operatorname{PrP}^{\mathrm{c}}$ in the context of HIV-CNS infection and its role in HIV neuropathogenesis. HIV enters the CNS within the first 2 weeks of primary infection mainly through infected monocytes crossing the BBB, and results in increased cytokine production, in particular TNF$\alpha[50,51]$. Increased VEGF has also been shown in reactive astrocytes during HIV neuropathogenesis [46, 52].

In this study, we showed that TNF- $\alpha$ and VEGF decrease cell surface $\operatorname{PrP}^{\mathrm{c}}$ in BMVEC. These factors also decreased $\operatorname{PrP}^{\mathrm{c}}$ mRNA, suggesting that they regulate de novo synthesis of this protein. We hypothesized that decreased $\operatorname{PrP}^{\mathrm{c}}$ expression will lead to endothelial monolayer integrity disruption and showed that $\operatorname{PrP}^{\mathrm{c}}$ knockdown in BMVEC leads to increased permeability in monolayers of BMVEC lacking $\operatorname{PrP}^{\mathrm{c}}$. We also showed that loss of $\operatorname{PrP}^{\mathrm{c}}$ leads to decreased expression of TJ proteins occludin and claudin-5, suggesting a mechanism by which $\operatorname{PrP}^{\mathrm{c}}$ knockdown leads to increased permeability of BMVEC monolayers. Therefore, we propose that during CNS disorders, inflammatory mediators that decrease $\operatorname{PrP}^{\mathrm{c}}$ expression in BMVEC contribute to CNS damage by increasing BBB permeability.

\section{Materials and methods}

\section{Brain microvascular endothelial cell culture and treatment}

Human BMVEC (Applied Cell Biology Research Institute, Kirkland, WA) were grown in M199 media, supplemented with $20 \%$ heat-inactivated newborn calf serum, $1 \%$ penicillin-streptomycin (all from Thermo Fisher Scientific, Waltham, MA), 0.8\% heparin (Sigma, St. Louis, MO), 5\% heat-inactivated human serum $\mathrm{AB}$ (Lonza, Walkersville, MD), $0.1 \%$ ascorbic acid (Sigma, St. Louis, MO), 0.25\% endothelial cell growth supplement (Sigma, St. Louis, MO), and $0.06 \%$ bovine brain extract (Clonetics, Walkersville, MD). Recombinant TNF- $\alpha$ (PeproTech, Rocky Hill, NJ) and recombinant VEGF (R\&D, Minneapolis, MN) were added directly to the cell culture media to a final concentration of $10 \mathrm{ng} / \mathrm{ml}$ and $100 \mathrm{ng} / \mathrm{ml}$, respectively.

\section{Western blotting}

BMVEC were grown to confluence on $0.2 \%$ gelatin (Fisher Scientific, Pittsburgh, PA) coated $60 \mathrm{~mm}$ tissue culture dishes. Cells were lysed with cell lysis buffer (Cell 
Signaling, Boston, MA) supplemented with protease inhibitor cocktail (Roche, Indianapolis, MN). Total cellular protein concentration was determined by Bio-Rad protein assay (Bio-Rad, Hercules, CA). Forty micrograms of cell lysate were loaded onto $4-20 \%$ polyacrylamide gels (BioRad), separated by electrophoresis, and transferred to nitrocellulose membranes (GE Healthcare Life Sciences, Pittsburgh, PA). Membranes were blocked for $2 \mathrm{~h}$ at room temperature with $5 \%$ nonfat dry milk and $3 \%$ bovine serum albumin (BSA) in Tris-Buffered Saline and $0.1 \%$ Tween 20 (TBST). Blots were probed with antibody against $\operatorname{PrP}^{\mathrm{c}}$ (SAF 32 clone, 1:200 dilution, Cayman Chemicals, MI) overnight at $4{ }^{\circ} \mathrm{C}$, washed with TBST, and probed with antimouse immunoglobulin G-horseradish peroxidase (IgGHRP) secondary antibody, 1:2000 dilution (Cell Signaling) for $1 \mathrm{~h}$ at room temperature. Signal was detected using Western Lightning Plus-ECL (Perkin Elmer, Waltham, MA). Blots were stripped using Restore Plus Western Blot Stripping Buffer (Thermo Scientific), and reprobed with antibody against glyceraldehyde 3-phosphate dehydrogenase (GAPDH), 1:500 dilution, (Cell Signaling), for $1 \mathrm{~h}$ at room temperature, washed with TBST and probed with anti-mouse IgG-HRP secondary antibody (1:2000 dilution) for $1 \mathrm{~h}$ at room temperature. Signal was detected using Western Lightning Plus-ECL. Data were quantified by densitometry using UN-SCAN-IT software (Silk Scientific, Orem, UT)

\section{Flow cytometry}

Surface $\operatorname{PrP}^{\mathrm{c}}$ was analyzed by flow cytometry using a fluorochrome-coupled $\mathrm{mAb}$ specific for human $\mathrm{PrP}^{\mathrm{c}}$ (eBioscience, San Diego, CA) and a corresponding isotypematched (mouse IgG1K) negative control antibody (eBioscience). Antibodies were titered to determine optimal concentration for staining $(0.25 \mu \mathrm{g} / 100 \mu \mathrm{l})$. BMVEC were dissociated with TrypLE (Thermo Scientific) and $1 \times 10^{5}$ cells were washed with FACS buffer, calcium, and magnesium-free phosphate-buffered saline (PBS) supplemented with 1\% BSA (Thermo Fisher Scientific). Cells were incubated in the dark on ice for 30 min with antibodies. Following staining, cells were washed with FACS buffer and fixed with $2 \%$ paraformaldehyde. A total of $1 \times$ $10^{5}$ events were acquired with a BD FACSCanto II flow cytometer and analyzed with FlowJo software (TreeStar, Ashland, OR).

\section{RNA isolation and qRT-PCR}

Total RNA was isolated from BMVEC $\left(1 \times 10^{6}\right)$ by Trizol (Life Technologies, Carlsbad, CA) extraction according to the manufacturer's instructions and quantified by Nanodrop (Thermo Scientific, Wilmington, DE). Complementary
DNA (cDNA) synthesis was performed using SuperScript VILO cDNA synthesis kit (Life Technologies). Relative mRNA expression of $\operatorname{PrP}^{\mathrm{c}}, 18 \mathrm{~S}$, and GAPDH was determined using a Taqman Gene Expression Assay (Life Technologies). Results are represented as relative expression of $\mathrm{PrP}^{\mathrm{c}}$ normalized to $18 \mathrm{~S}$ and/or GAPDH as housekeeping genes using $2^{-\Delta \mathrm{Ct}}$. The $\Delta \mathrm{Ct}$ value was determined by subtracting the average $\mathrm{Ct}$ of the housekeeping gene from the average $\mathrm{Ct}$ of $\mathrm{PrP}^{\mathrm{c}}$.

\section{PrPc knockdown with shRNA}

shRNAs corresponding to the human PRNP gene were synthesized by the shRNA Core at Albert Einstein College of Medicine. These shRNA clones were built on the pGIPZ vector [53] that encodes green fluorescent protein (GFP) and a puromycin selection marker making it possible to monitor and select transfected cells. To generate $\operatorname{PrP}^{\mathrm{c}}$ knockdown cell lines, BMVEC were infected with three lentiviruses carrying three different shRNA's, with an multiplicity of infection of 80 in the presence of polybrene $(5 \mu \mathrm{g} / \mathrm{ml})$ (Sigma) for $48 \mathrm{~h}$. Cells were grown to confluence in fresh media for an additional $48 \mathrm{~h}$. Transfected cells were selected with puromycin $(0.5 \mu \mathrm{g} / \mathrm{ml})$ (Sigma) and maintained in puromycin containing media. Three different cell lines with different shRNA sequences were generated. The specific shRNA sequences used were $5^{\prime}$-TGCATGTTCTTGTTTTGTT- $3^{\prime}$ for PrP ${ }^{c} \mathrm{KD} 1$, 5'-GACATATTCACAGTGAACA-3' for $\operatorname{PrP}^{\mathrm{c}} \mathrm{KD} 2$, and $5^{\prime}$-TGCGTCAATATCACAATCA-3' for PrP ${ }^{\mathrm{c}} \mathrm{KD} 3$. These three shRNAs target different regions in the 3'-UTR of the PRNP gene. A lentivirus with a pGIPZ vector with no PRNP shRNA was used as a control. To assay for knockdown of $\operatorname{PrP}^{\mathrm{c}}$, we determined the level of $\operatorname{PrP}^{\mathrm{c}}$ mRNA in the different cell lines and found mRNA reduction of 90,25 , and $80 \%$ in $\operatorname{PrP}^{\mathrm{c}} \mathrm{KD} 1, \operatorname{PrP}^{\mathrm{c}} \mathrm{KD} 2$, and $\operatorname{PrP}^{\mathrm{c}} \mathrm{KD} 3$, respectively. We also assayed for reduction in surface $\operatorname{PrP}^{\mathrm{c}}$ by flow cytometry and found 90, 40, and $86 \%$ reduction in surface $\operatorname{PrP}^{\mathrm{c}}$ in $\operatorname{PrP}^{\mathrm{c}} \mathrm{KD} 1$, $\operatorname{PrP}^{\mathrm{c}} \mathrm{KD} 2$, and $\operatorname{PrP}^{\mathrm{c}} \mathrm{KD} 3$, respectively.

\section{Permeability measurement}

Transfected BMVEC were plated on tissue culture inserts with $3 \mu \mathrm{m}$ pores (Corning, Corning, NY) at $4 \times 10^{4}$ cells per insert and grown to confluence for 3-4 days. Cultures were maintained in puromycin containing media. Inserts were washed with phenol red-free Dulbecco's Modified Eagle Medium (DMEM) (Thermo Fisher Scientific) and placed in 24-well tissue culture plates containing $400 \mu \mathrm{L}$ of phenol red-free DMEM/10\% fetal bovine serum in each well. Dextran-FITC $(125 \mu \mathrm{g} / \mathrm{mL}, 70 \mathrm{kDa}$, Sigma) $(200 \mu \mathrm{L})$ was added to the top of the insert, and after 5 min at $37^{\circ} \mathrm{C}$, media was collected from the lower chamber and fluorescence was analyzed with a fluorescence- 
A
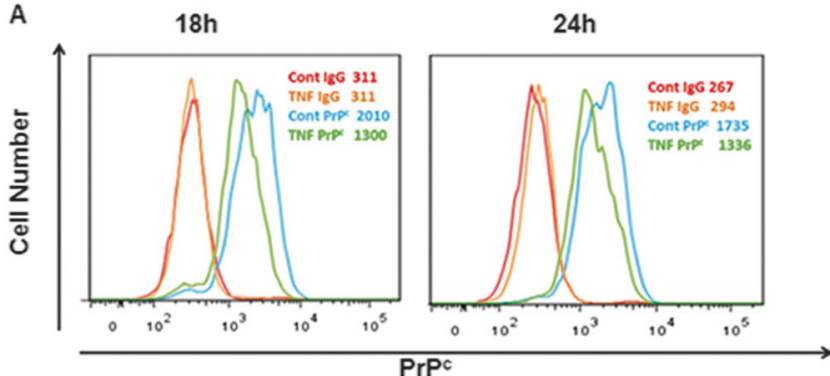

C

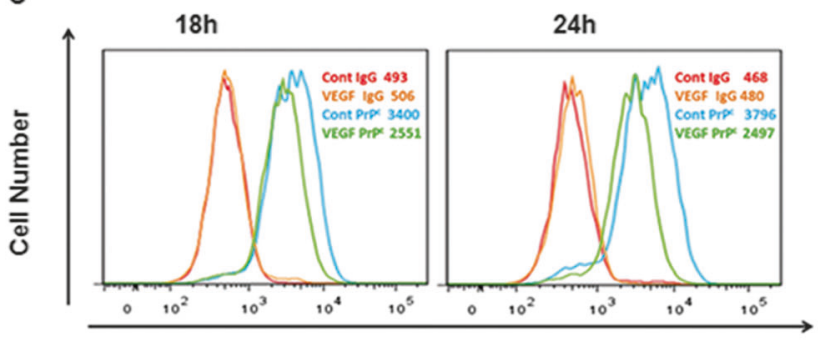

$24 \mathrm{~h}$

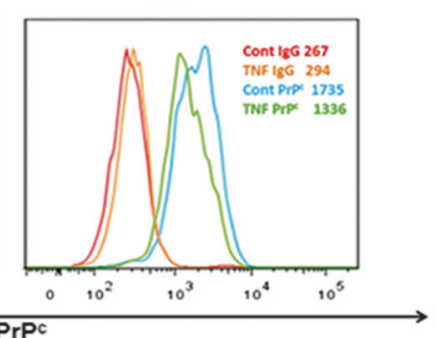

$\operatorname{PrPc}$
B

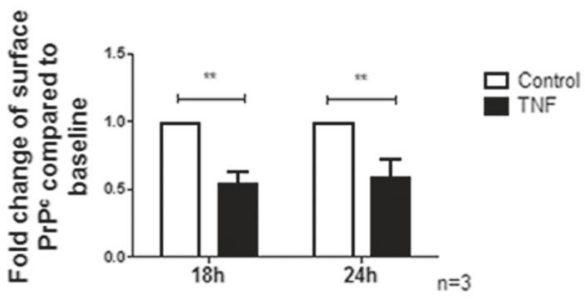

D

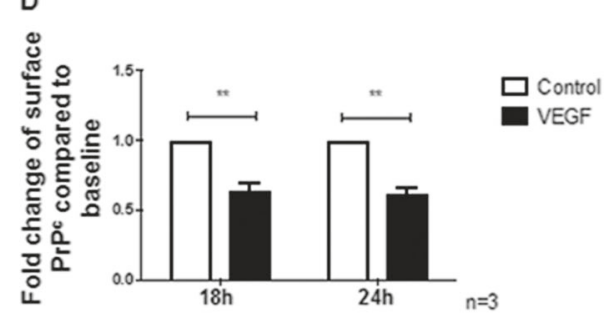

Fig. 1 TNF- $\alpha$ and VEGF decrease $\operatorname{PrP}^{\mathrm{c}}$ surface expression on endothelial cells. Surface $\operatorname{PrP}^{c}$ was analyzed by flow cytometry after treatment with TNF- $\alpha(10 \mathrm{ng} / \mathrm{ml})$ or VEGF $(100 \mathrm{ng} / \mathrm{ml})$. a Representative plot showing the change in surface $\operatorname{PrP}^{c}$ determined by FACS analysis after treatment with TNF- $\alpha$ for $18 \mathrm{~h}$ and $24 \mathrm{~h}$. Three independent experiments were quantified. $\mathbf{b}$ The fold change in mean fluorescence intensity (MFI) of $\mathrm{PrP}^{\mathrm{c}}$ on BMVEC after TNF- $\alpha$ treatment as compared with control was calculated after subtracting the contribution of the isotype-matched negative control antibody. Surface $\mathrm{PrP}^{\mathrm{c}}$ after $18 \mathrm{~h}$ and $24 \mathrm{~h}$ of $\mathrm{TNF}-\alpha$ treatment decreased by 0.5 -fold

detecting plate reader (excitation $\lambda 488 \mathrm{~nm}$; emission $\lambda 510 \mathrm{~nm})$.

\section{Immunofluorescence}

Primary BMVEC were grown to confluence on $0.2 \%$ gelatin (Fisher Scientific) coated $35 \mathrm{~mm}$ ibiTreat dishes (ibidi USA, Madison, WI). Cells were fixed in 4\% paraformaldehyde (Electron Microscopy Sciences, Hatfield, PA) for $30 \mathrm{~min}$ and permeablized in $0.01 \%$ Triton $\mathrm{X}-100$ for $1 \mathrm{~min}$. Blocking was performed for $2 \mathrm{~h}$ at room temperature with $5 \mathrm{mM}$ ethylenediaminetetraacetic acid (Thermo Fisher Scientific), $1 \%$ fish gelatin (Sigma), $1 \%$ essentially immunoglobulin-free BSA (Sigma), 1\% heat-inactivated human serum type AB (Lonza), and $1 \%$ goat serum (Vector, Burlingame, CA, USA) in deionized water. Cells were incubated overnight at $4^{\circ} \mathrm{C}$ in primary antibody antioccludin, (Abcam, Cambridge, MA), and anti-claudin-5 (Santa Cruz Biotechnology, Dallas, TX) diluted 1:500 and $1: 300$, respectively. Cells were washed three times with PBS at room temperature and incubated with the appropriate secondary antibodies conjugated to $\mathrm{Cy} 3$, and labeled with phalloidin to identify the shape of the cells. ibiTreat dishes were then mounted using antifade reagent with DAPI
(50\%) and 0.4-fold (40\%), respectively. c Representative plot showing the change in surface $\operatorname{PrP}^{\mathrm{c}}$ determined by FACS analysis after treatment with VEGF for $18 \mathrm{~h}$ and $24 \mathrm{~h} \mathrm{~d}$. The fold change in MFI of $\operatorname{PrP}^{\mathrm{c}}$ on BMVEC after VEGF treatment as compared with control was calculated after subtracting the contribution of the isotype-matched negative control antibody. Surface $\operatorname{PrP}^{\mathrm{c}}$ after $18 \mathrm{~h}$ and $24 \mathrm{~h}$ of VEGF treatment decreased by 0.4 -fold $(40 \%)$ and 0.5 -fold $(50 \%)$, respectively. Significance was determined using a two-tailed paired Student $t$ test. ${ }^{*} p<0.05, * * p<0.01$

to identify nuclei and the cells were then examined by confocal microscopy using a Nikon A1 confocal microscope with spectrum detection (Nikon, Tokyo, Japan). Owing to the nature of the distribution of occludin and claudin-5 in BMVEC, we identified XY areas that were positive for $\operatorname{PrP}^{\mathrm{c}}$ siRNA (areas that were GFP positive) and stained as described above. After identifying the cells that were positive for $\operatorname{PrP}^{\mathrm{c}}$ siRNA, we characterized the intracellular and membrane expression by positivity for actin filament and membrane expression by lack of positivity for actin. Using the previous acquired XY coordinates with GFP from the $\operatorname{PrP}^{\mathrm{c}}$ siRNA, we compared the expression in areas with or without knockdown using NIS elements by quantifying the numbers of positive pixels for each location.

\section{Results}

\section{TNF- $a$ and VEGF decrease surface PrP ${ }^{c}$ from BMVEC}

BMVEC monolayers are characterized by the presence of intercellular $\mathrm{TJ}$ and adhesion proteins, and are a major component of the $\mathrm{BBB}$. The $\mathrm{BBB}$ contributes to cerebral homeostasis and controls leukocyte migration, as well as 

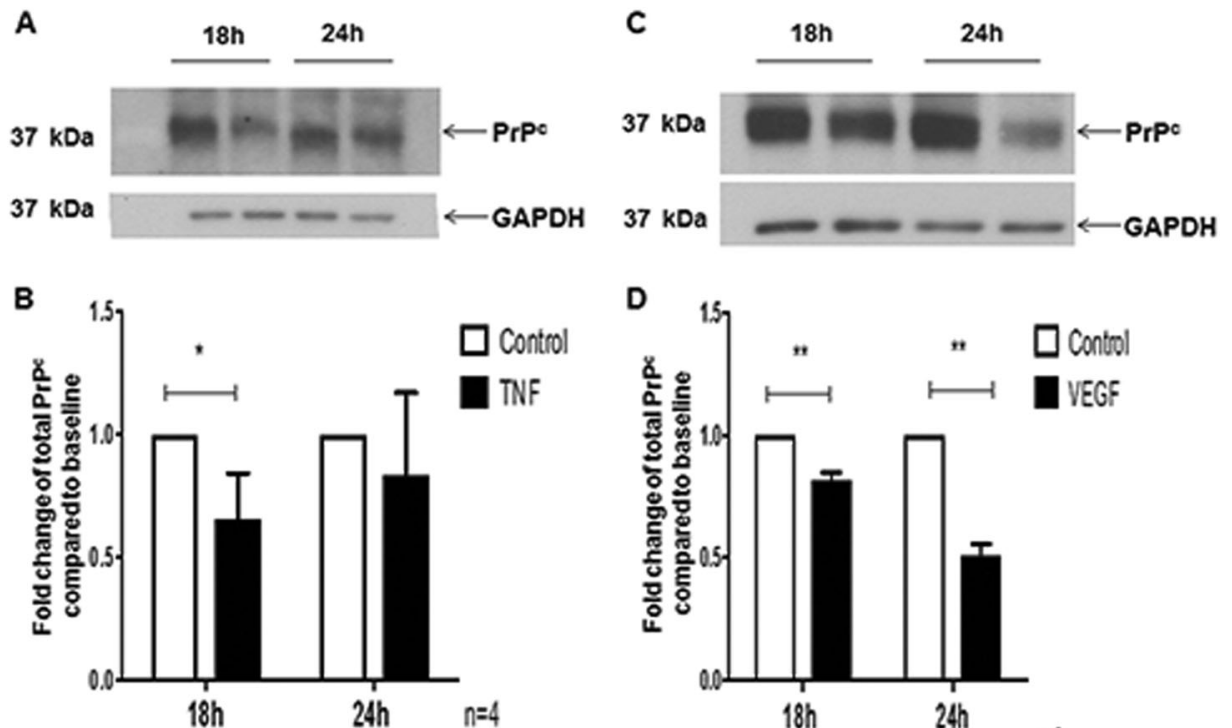

Fig. 2 TNF- $\alpha$ and VEGF decrease total $\operatorname{PrP}^{c}$ in endothelial cells. a Representative blot showing $\operatorname{PrP}^{\mathrm{c}}$ decrease in BMVEC treated with TNF- $\alpha(10 \mathrm{ng} / \mathrm{ml})$ for either $18 \mathrm{~h}$ or $24 \mathrm{~h}$ and lysates prepared to examine total $\operatorname{PrP}^{\mathrm{c}}$ by western blotting. GAPDH was used as a loading control. b Four independent experiments were quantified. TNF- $\alpha$ decreased total $\operatorname{PrP}^{\mathrm{c}}$ by 0.4 -fold $(40 \%)$ at $18 \mathrm{~h}$ with $\operatorname{PrP}^{\mathrm{c}}$ returning to baseline at $24 \mathrm{~h}$. c Representative blot showing $\operatorname{PrP}^{\mathrm{c}}$ decrease in

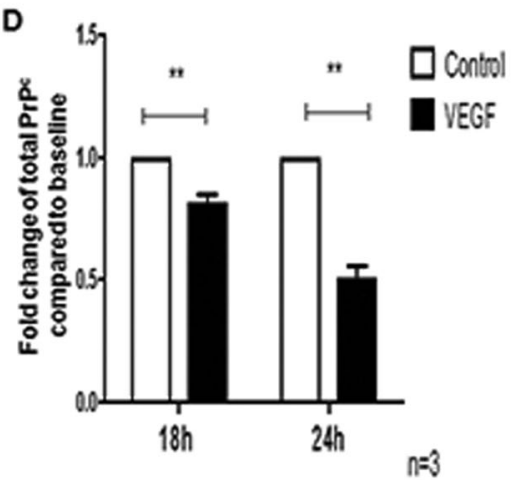

BMVEC treated with VEGF $(100 \mathrm{ng} / \mathrm{ml})$ for either $18 \mathrm{~h}$ or $24 \mathrm{~h}$ and lysates prepared to examine total $\operatorname{PrP}^{c}$ by western blotting. GAPDH was used as a loading control. d Three independent experiments were quantified. VEGF decreased total $\operatorname{PrP}^{\mathrm{c}}$ by 0.2 -fold $(20 \%)$ at $18 \mathrm{~h}$ and by 0.6 -fold $(60 \%)$ at $24 \mathrm{~h}$. Significance was determined using a twotailed paired Student's $t$ test. $* p<0.05, * * p<0.01$

pathogen invasion, into the brain [19-21]. Immunofluorescence, as detected by confocal microscopy, showed that $\operatorname{PrP}^{\mathrm{c}}$ was localized to junctions between adjacent endothelial cells similar to the adhesion protein platelet endothelial cell adhesion molecule-1, suggesting that $\mathrm{PrP}^{\mathrm{c}}$ may be part of endothelial adhesion complexes that maintain integrity of the endothelial monolayer [9]. In intestinal epithelial cells, $\operatorname{PrP}^{\mathrm{c}}$ localizes to adhesion complexes as surface $\operatorname{PrP}^{c}$ has been shown to regulate intestinal barrier functions [26].

TNF- $\alpha$ increases BBB permeability directly by downregulating TJ proteins occludin, claudin-5, and ZO-1 and indirectly by inducing the production of chemokines and cytokines that regulate $\mathrm{TJ}$ and adherence junctions (AJ) proteins and affect barrier integrity [54, 55]. VEGF decreases endothelial barrier permeability by downregulating claudin-5 and occludin [46]. We hypothesized that another mechanism by which these inflammatory factors disrupt TJ formation and BBB integrity is by changing the surface expression of $\operatorname{PrP}^{\mathrm{c}}$.

To determine the effect of TNF- $\alpha$ and VEGF on cell surface $\operatorname{PrP}^{\mathrm{c}}$, human BMVEC were cultured to confluence on $0.2 \%$ gelatin-coated tissue cultures plates. Cultures were treated with VEGF $(100 \mathrm{ng} / \mathrm{ml})$ or TNF- $\alpha(10 \mathrm{ng} / \mathrm{ml})$ for $18 \mathrm{~h}$ and $24 \mathrm{~h}$. Earlier time points, $30 \mathrm{~min}, 6 \mathrm{~h}$, and $12 \mathrm{~h}$ were examined and we determined that significant decreases in $\operatorname{PrP}^{\mathrm{c}}$ expression occur starting at $18 \mathrm{~h}$ post treatment.

Cells were dissociated from plates using TrypLE and stained with $\operatorname{PrP}^{\mathrm{c}}$ antibody or isotype-matched control antibody and analyzed by flow cytometry.

Fold changes in $\operatorname{PrP}^{\mathrm{c}}$ mean fluorescent intensity after TNF- $\alpha$ or VEGF treatments were compared with control untreated cells, which was set to one. Changes in $\operatorname{PrP}^{\mathrm{c}}$ mean fluorescence were determined by subtracting the mean fluorescent intensity of the isotype-matched negative control antibody from the mean fluorescent intensity of the $\operatorname{PrP}^{\mathrm{c}}$-specific antibody. TNF- $\alpha$ treatment decreased surface $\mathrm{PrP}^{\mathrm{c}}$ on human BMVEC at $18 \mathrm{~h}$ and $24 \mathrm{~h}$ as shown by a representative histogram (Fig. 1a). Quantification of three independent experiments shows that TNF- $\alpha$ decreases $\operatorname{PrP}^{\mathrm{c}}$ by 0.5 - and 0.4 -fold at $18 \mathrm{~h}$ and $24 \mathrm{~h}$, respectively (Fig. $1 \mathrm{~b}$, $\left.{ }^{* *} p<0.01\right)$. Similarly, VEGF decreased surface $\operatorname{PrP}^{\mathrm{c}}$ on human BMVEC at $18 \mathrm{~h}$ and $24 \mathrm{~h}$ as shown by a representative histogram (Fig. 1c). Quantification of three independent experiments shows that VEGF decreases $\operatorname{PrP}^{\mathrm{c}}$ by 0.4 -fold at $18 \mathrm{~h}$ and by 0.5 -fold at $24 \mathrm{~h}$ (Fig. $1 \mathrm{~d}$, $* * p<0.01$ ). For both mediators, this is a $40-50 \%$ reduction, which are highly significant.

\section{TNF- $a$ and VEGF decrease total PrPc in BMVEC}

To determine whether TNF- $\alpha$ and VEGF decrease surface $\mathrm{PrP}^{\mathrm{c}}$ by changing the localization of this protein or by decreasing total protein levels of $\operatorname{PrP}^{\mathrm{c}}$, we treated BMVEC 
with these factors and studied changes in total $\operatorname{PrP}^{\mathrm{c}}$ protein by western blotting. Cells were grown to confluence and treated with TNF- $\alpha$ and VEGF for $18 \mathrm{~h}$ or $24 \mathrm{~h}$, after which cell lysates were prepared and changes in total $\operatorname{PrP}^{\mathrm{c}}$ were quantified. Densitometry was performed in which total $\operatorname{PrP}^{\mathrm{c}}$ was compared with a loading control, GAPDH, and these values were compared between control and TNF- $\alpha$-treated cells, and control and VEGF-treated cells. Results are reported as fold change relative to control. We found that TNF- $\alpha$ decreased total $\operatorname{PrP}^{\mathrm{c}}$ by 0.4 -fold $(40 \%)$ at $18 \mathrm{~h}$ and that $\operatorname{PrP}^{\mathrm{c}}$ protein levels returned to baseline by $24 \mathrm{~h}$ (Fig. 2a, $\left.\mathrm{b},{ }^{*} p<0.05\right)$. VEGF decreased total $\mathrm{PrP}^{\mathrm{c}}$ in BMVEC by 0.2 -fold $(20 \%)$ at $18 \mathrm{~h}$ and by 0.6 -fold $(60 \%)$ at $24 \mathrm{~h}$ (Fig. $2 \mathrm{c}, \mathrm{d},{ }^{*} p<0.05$ ). These results suggest that during neuroinflammation, total $\operatorname{PrP}^{\mathrm{c}}$ in BMVEC is downregulated by inflammatory factors. We propose that this downregulation in turn may negatively impact endothelial function by decreasing barrier integrity.

\section{TNF- $a$ and VEGF decrease PrPc gene expression in BMVEC}

To examine the mechanism by which TNF- $\alpha$ and VEGF regulate $\operatorname{PrP}^{\mathrm{c}}$, we treated BMVEC with these mediators and analyzed PrP ${ }^{\mathrm{c}}$ mRNA by qRT-PCR. We found that TNF- $\alpha$ decreased $\operatorname{PrP}^{\mathrm{c}}$ mRNA at $12 \mathrm{~h}$ and $18 \mathrm{~h}$ by 0.2 -fold $(20 \%)$ and 0.4-fold (40\%), respectively. By $24 \mathrm{~h}, \operatorname{PrP}^{\mathrm{c}}$ message returned to baseline (Fig. 3a, ${ }^{*} p<0.05$ ). VEGF decreased $\operatorname{PrP}^{\mathrm{c}}$ mRNA significantly at $12 \mathrm{~h}, 18 \mathrm{~h}$, and $24 \mathrm{~h}$ in BMVEC by 0.4 -fold $(40 \%), 0.5$-fold (50\%), and 0.6-fold (60\%), respectively, (Fig. $3 \mathrm{~b}, * p<0.05$ and $* * * p<0.0005$ ). These results indicate that TNF- $\alpha$ and VEGF decrease de novo synthesis of $\operatorname{PrP}^{\mathrm{c}}$.

\section{shRNA interference decreases surface PrPc on BMVEC}

To examine the specific role of $\operatorname{PrP}^{\mathrm{c}}$ in endothelial barrier integrity and function and the consequences of its downregulation, we generated three different $\operatorname{PrP}^{\mathrm{c}}$ knockdown BMVEC cell lines using shRNA interference. Cells were infected with lentivirus carrying shRNA against PRNP (the $\mathrm{PrP}^{\mathrm{c}}$ gene) and GFP and puromycin selection markers (as described in Materials and methods). Control cells were infected with a lentivirus vector that did not contain PRNP shRNA. Cells were grown to confluence in puromycin containing media. Infections were performed two independent times with the three shRNAs described.

To confirm that $\operatorname{PrP}^{\mathrm{c}}$ mRNA was reduced in the BMVEC, we analyzed $\operatorname{PrP}^{c}$ mRNA in the three different cell lines by qRT-PCR. All cells lines were generated using the same donor of BMVEC, but unique shRNA sequences that target different regions of the 3 '-UTR of the $\operatorname{PrP}^{\mathrm{c}}$ gene.
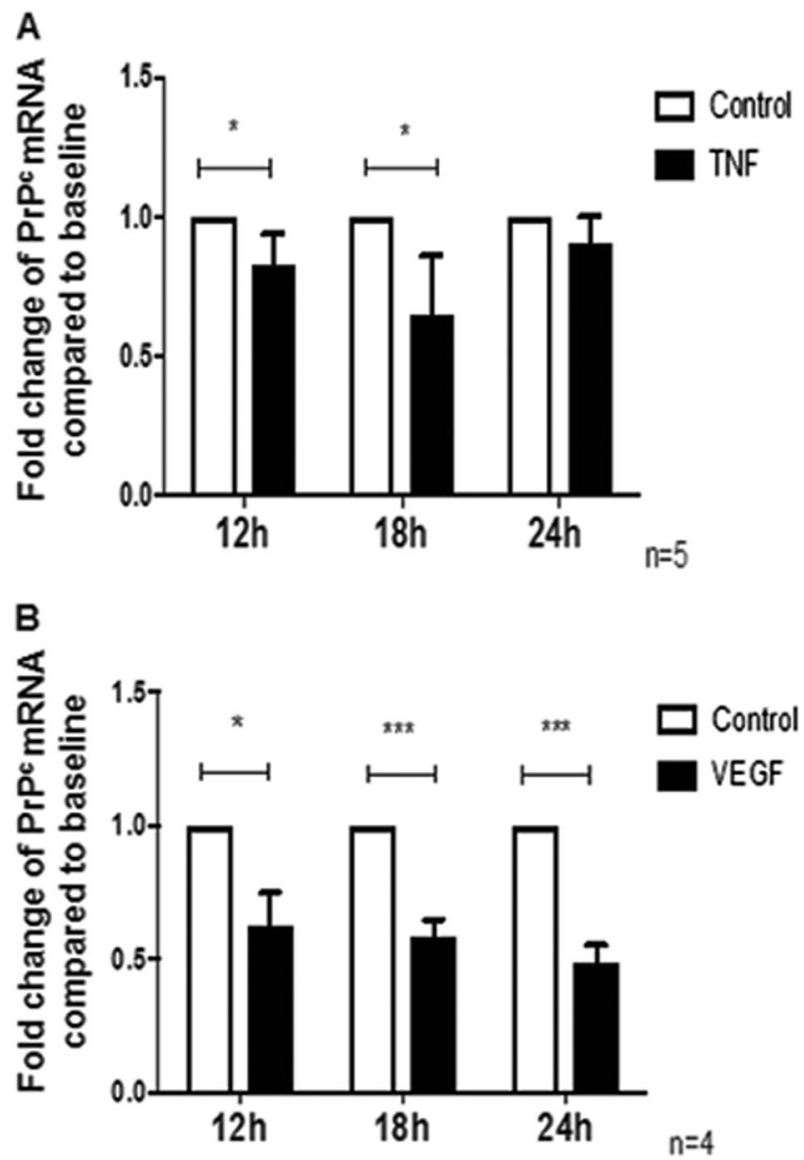

Fig. 3 TNF- $\alpha$ and VEGF decrease $\operatorname{PrP}^{\mathrm{c}}$ mRNA in endothelial cells. a BMVEC were treated with TNF- $\alpha(10 \mathrm{ng} / \mathrm{ml})$ for $12 \mathrm{~h}, 18 \mathrm{~h}$, or $24 \mathrm{~h}$ and mRNA levels of $\operatorname{PrP}^{c}$ were evaluated using qRT-PCR. TNF- $\alpha$ decreased $\operatorname{PrP}^{\mathrm{c}}$ mRNA at $12 \mathrm{~h}$ and $18 \mathrm{~h}$ by 0.2 -fold $(20 \%)$ and 0.4 -fold (40\%), respectively, and $\operatorname{PrP}^{\mathrm{c}}$ mRNA returned to baseline at $24 \mathrm{~h}$, $n=5$. b BMVEC were treated with VEGF (100 ng/ml) for $12 \mathrm{~h}, 18 \mathrm{~h}$, or $24 \mathrm{~h}$ and mRNA levels of $\operatorname{PrP}^{\mathrm{c}}$ were evaluated using qRT-PCR. VEGF decreased $\mathrm{PrP}^{\mathrm{c}}$ mRNA by 0.4 -fold (40\%), 0.5-fold (50\%), and 0.6 -fold $(60 \%)$ at $12 \mathrm{~h}, 18 \mathrm{~h}$, and $24 \mathrm{~h}$, respectively, $n=3$. Significance was determined using a two-tailed paired Student's $t$ test. ${ }^{*} p<0.05$, $* * p<0.01, * * * p<0.0005$

We found that shRNA knockdown of the PRNP gene resulted in a $90 \%$ reduction of $\operatorname{PrP}^{\mathrm{c}}$ mRNA in one cell line $\left(\mathrm{PrP}^{\mathrm{c}} \mathrm{KD} 1\right)$ as compared with the control cell line. In two other cell lines, shRNA knockdown resulted in $25 \%$ and $80 \%$ reduction of $\mathrm{PrP}^{\mathrm{c}}$ mRNA. These cell lines were termed $\mathrm{PrP}^{\mathrm{c}} \mathrm{KD} 2$ and $\operatorname{PrP}^{\mathrm{c}} \mathrm{KD} 3$, respectively (Fig. $4 \mathrm{a},{ }^{*} p<0.05$ and $* * p<0.01)$.

We also analyzed changes in surface $\operatorname{PrP}^{\mathrm{c}}$ levels in the shRNA knockdown BMVEC lines by flow cytometry. BMVEC were dissociated from plates using TrypLE and stained with $\operatorname{PrP}^{\mathrm{c}}$ antibody or isotype-matched control antibody and analyzed by flow cytometry. Changes in $\operatorname{PrP}^{\mathrm{c}}$ mean fluorescence were determined by subtracting the mean fluorescent intensity of the isotype-matched negative control antibody from the mean fluorescent intensity of the 

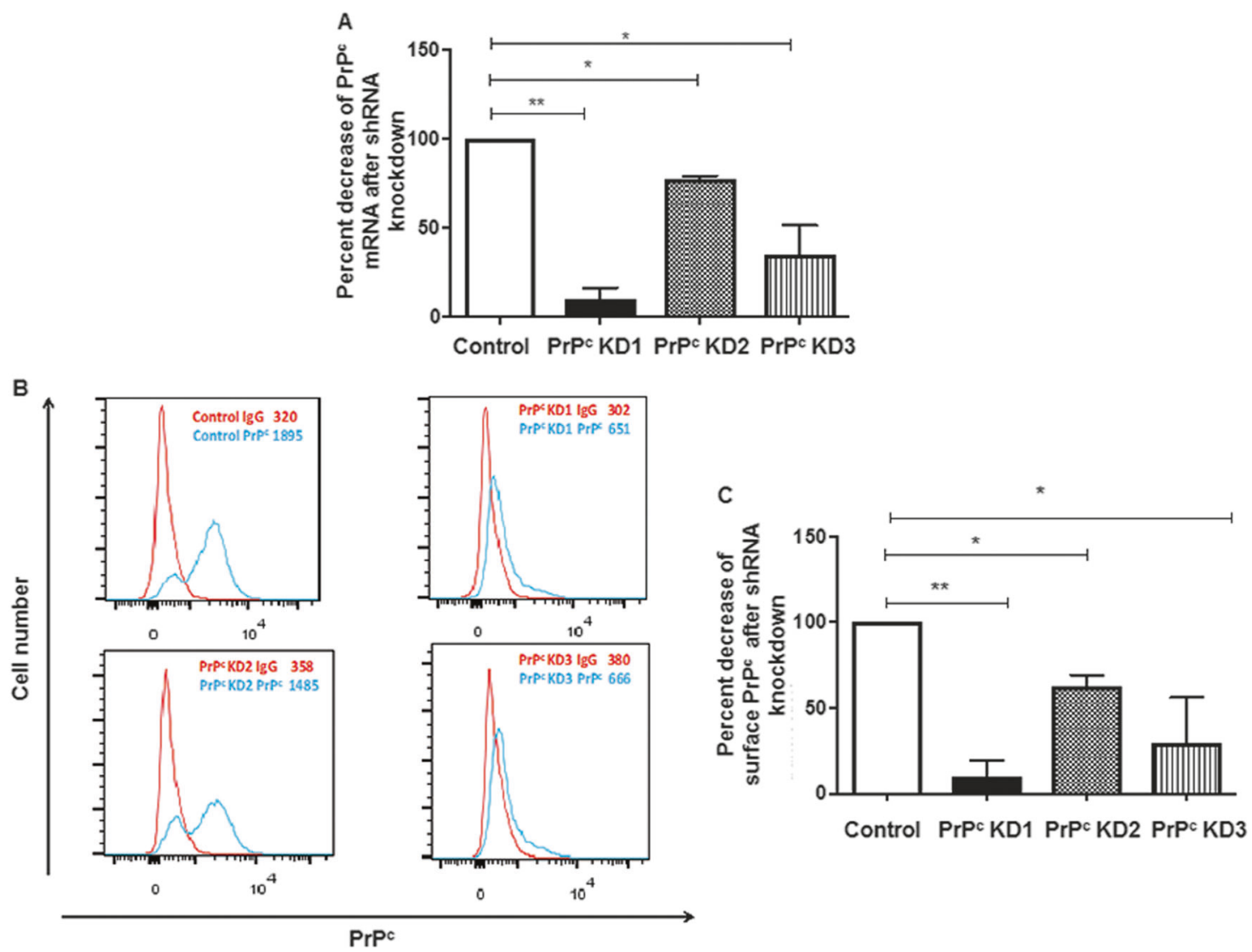

Fig. 4 Significant knockdown of $\operatorname{Pr}^{\mathrm{c}}$ in BMVEC with shRNA. a mRNA levels of $\operatorname{PrP}^{\mathrm{c}}$ were analyzed by qRT-PCR in control cells and three lines infected with PRNP shRNA. One cell line $\left(\operatorname{PrP}^{\mathrm{c}} \mathrm{KD} 1\right)$ showed 90\% decrease in $\operatorname{PrP}^{\mathrm{c}}$ mRNA. The second cell line ( $\left.\operatorname{PrP}^{\mathrm{c}} \mathrm{KD} 2\right)$ and the third cell line $\left(\operatorname{PrP}^{\mathrm{C}} \mathrm{KD} 3\right)$ showed $25 \%$ and $65 \%$ fold decrease in $\operatorname{PrP}^{\mathrm{c}}$ mRNA, respectively. b Surface $\operatorname{PrP}^{\mathrm{c}}$ was analyzed by flow cytometry in control cell lines and three cell lines that were infected

$\mathrm{PrP}^{\mathrm{c}}$-specific antibody. We found that shRNA knockdown of the PRNP gene resulted in $90 \%$ reduction of cell surface $\operatorname{PrP}^{\mathrm{c}}$ in the cell line $\operatorname{PrP}^{\mathrm{c}} \mathrm{KD} 1 . \operatorname{PrP}^{\mathrm{c}} \mathrm{KD} 2$ and $\mathrm{PrP}^{\mathrm{C}} \mathrm{KD} 3$ showed $40 \%$ and $70 \%$ reduction of cell surface $\mathrm{PrP}^{\mathrm{c}}$, respectively (Fig. $4 \mathrm{c}, * p<0.05$ and $* * p<0.01$ ). Although all $\mathrm{PrP}^{\mathrm{c}} \mathrm{KD} 2$ cells were GFP positive, indicating that they had lentivirus incorporated into their genome, only a percentage of these cells exhibited a decrease in $\operatorname{PrP}^{\mathrm{c}}$ as shown on the FACS histograms (Fig. 4b). PrP ${ }^{\mathrm{c}}$ knockdown did not affect cell proliferation or viability as evidenced by counting of cells with trypan blue staining.

\section{PrPc contributes to barrier integrity in BMVEC}

To examine whether $\operatorname{PrP}^{\mathrm{c}}$ knockdown results in changes in permeability, control and PRNP shRNA-transfected BMVEC were cultured on gelatin-coated $3 \mu \mathrm{m}$ pore culture inserts placed in 24-well tissue culture plates. Changes in permeability of BMVEC monolayers of $\operatorname{PrP}^{\mathrm{c}}$ with lentivirus containing PRNP shRNA. c Change in the mean fluorescence intensity (MFI) of $\operatorname{PrP}^{\mathrm{c}}$ on BMVEC cell lines infected with PRNP shRNA as compared with control was calculated after subtracting the contribution of the isotype-matched negative control antibody. $\operatorname{PrP}^{\mathrm{c}} \mathrm{KD} 1$ showed a $90 \%$ decrease in surface $\operatorname{PrP}^{\mathrm{c}}$, whereas $\operatorname{PrP}^{\mathrm{c}}$ KD2 showed a 40\% decrease in surface $\operatorname{PrP}^{\mathrm{c}}$ and $\operatorname{PrP}^{\mathrm{c}}$ KD3 showed a $70 \%$ decrease in $\operatorname{PrP}^{\mathrm{c}}$

knockdown cell lines were assessed by the movement of dextran-FITC (70 kDA) across the monolayers. DextranFITC $(125 \mu \mathrm{g} / \mathrm{mL})$ was added to the top of the insert, and after $5 \mathrm{~min}$ at $37^{\circ} \mathrm{C}$, media was collected from the lower chamber and fluorescence determined. In cell lines that exhibited 90\% knockdown of $\operatorname{PrP}^{\mathrm{c}}\left(\mathrm{PrP}^{\mathrm{c}} \mathrm{KD} 1\right)$, permeability increased by twofold as compared with control cell lines. The cell line with a $25 \%$ decrease in $\operatorname{PrP}^{\mathrm{c}}$ mRNA $\left(\mathrm{PrP}^{\mathrm{c}} \mathrm{KD} 2\right)$ did not show any change in permeability, whereas $\operatorname{PrP}^{c} \mathrm{KD} 3$ showed a 1.5 -fold increase in permeability (Fig. $5, * p<0.05$ and $* * * p<0.0005$ ). In previous studies, we have used other measurements of barrier integrity including transendothelial electrical resistance and flux of albumin conjugated to Evans blue dye across monolayers [56, 57]. Measurement of movement of dextran-FITC across BMVEC monolayers is comparable to measurement with Evans blue dye conjugated to albumin, and therefore we used dextran-FITC to assess permeability in this study. 


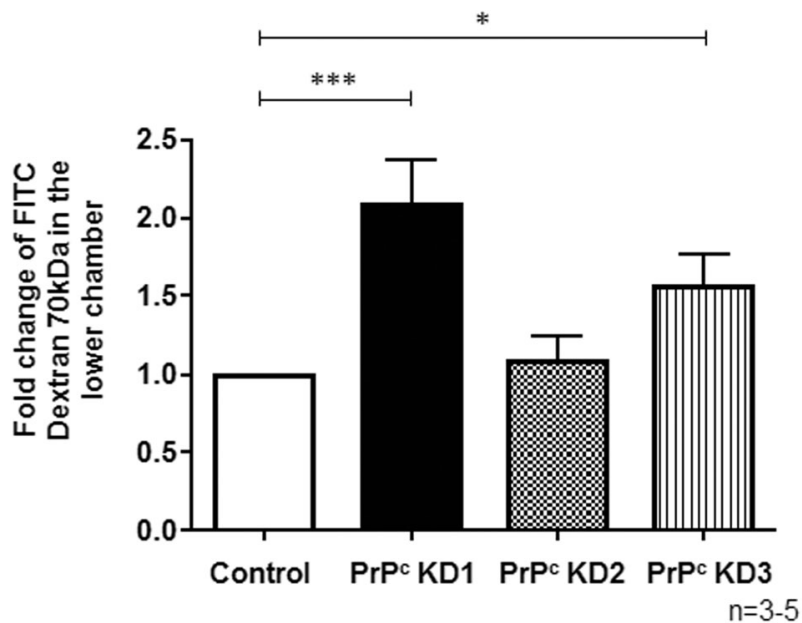

Fig. $5 \operatorname{PrP}^{\mathrm{c}}$ knockdown results in increased BMVEC monolayer permeability. Permeability was measured by the passage of dextran-FITC (70kDA) across BMVEC monolayer. Transfected BMVECs were cultured on tissue culture inserts with $3 \mu \mathrm{m}$ pores placed in 24-well tissue culture plates. Permeability of the barrier was measured by passage of dextran-FITC $(70 \mathrm{kDA})(125 \mathrm{ug} / \mathrm{ml})$ as described in the Materials and methods section. The cell line with a $90 \%$ knockdown of $\operatorname{PrP}^{c}\left(\operatorname{PrP}^{c} \mathrm{KD} 1\right)$ showed a 2.0-fold increase in permeability as compared to control cell lines. $\operatorname{PrP}^{c} \mathrm{KD} 2$, which has a $40 \%$ knockdown of $\mathrm{PrP}^{\mathrm{c}}$, showed no increase in permeability while $\operatorname{PrP}^{\mathrm{c}} \mathrm{KD} 3$, which has a $70 \%$ knockdown of $\operatorname{PrP}^{\mathrm{c}}$, showed a 1.6-fold increase in permeability. Significance was determined using a two-tailed paired Student's $t$ test. $* p<0.01, * * * p<0.0005$

\section{PrPc knockdown downregulates total and membrane-associated expression of occludin and claudin-5}

To examine the mechanism by which $\operatorname{PrP}^{\mathrm{c}}$ silencing leads to increased permeability of BMVEC monolayers, we studied the expression of occludin and claudin-5 in BMVEC, which have decreased $\mathrm{PrP}^{\mathrm{c}}$. In human Caco-2/TC7 enterocytes, downregulation of $\operatorname{PrP}^{\mathrm{c}}$ changes the localization and expression of TJ proteins [26]. We hypothesized that the absence of $\operatorname{PrP}^{\mathrm{c}}$ on BMVEC will lead to downregulation and redistribution of these TJ proteins on the cell surface, which leads to a leaky barrier. To examine whether $\operatorname{PrP}^{\mathrm{c}}$ is required for expression and localization of occludin and claudin-5 in BMVEC, total expression and localization of these TJ proteins in our KD lines was assessed by confocal microscopy and subsequent imaging analysis. We used actin as an intercellular marker. Proteins that did not localize with, but that were close to actin were considered membrane proteins. Control cells had $40-50 \%$ of their total occludin as membrane protein (Fig. $6 \mathrm{a}, \mathrm{b}$ ). $\operatorname{PrP}^{\mathrm{c}} \mathrm{KD} 1$ and $\mathrm{PrP}^{\mathrm{c}} \mathrm{KD} 3 \mathrm{had}$ reduced total occludin expression ((Fig. 6b, black bars, $* p \leq 0.001$ as compared with control) as well as reduced membrane occludin (Fig. 6b, red bars, $\# p \leq 0.0002$ as compared with membrane control). Using the same approach described for occludin, we performed analysis for claudin-5. $\operatorname{PrP}^{\mathrm{c}} \mathrm{KD} 1$ and $\operatorname{PrP}^{\mathrm{c}} \mathrm{KD} 3$ had reduced total expression of claudin-5 as well as cell-to cell membrane localization (Figs. 6c, d). This change was not as pronounced as for occludin but the reduction was significant. Negative controls using IgGs and control sera did not show positive staining (data not shown). Thus, $\operatorname{PrP}^{\mathrm{c}}$ knockdown decreased expression and membrane localization of occludin and claudin-5.

\section{Discussion}

The BBB, consisting primarily of BMVEC and astrocyte foot processes, separates the brain from the periphery [58]. TJ proteins, including occludin and claudin-5, connect adjacent BMVEC and restrict paracellular transmigration, rendering the barrier semi permeable [59, 60].

$\mathrm{PrP}^{\mathrm{c}}$ is an adhesion molecule expressed at cell junctions in endothelial and epithelial cells [7]. In brain endothelial cells isolated from mice, rats, and humans, this protein was localized at intercellular junctions between two adjacent cells [9]. In the same study, anti-PrP ${ }^{\mathrm{c}}$ antibodies blocked the migration of U937 human monocytic cell line and freshly isolated human monocytes across a human endothelial monolayer, suggesting $\operatorname{PrP}^{\mathrm{c}}$ is a junctional protein in BMVEC and that it is essential for monocyte migration across the $\mathrm{BBB}$ [9]. $\mathrm{PrP}^{\mathrm{c}}$ is also localized at cell junctions in human enterocytes and keratinocytes [7, 61]. This junctional localization of $\operatorname{PrP}^{\mathrm{c}}$ is dependent on the expression of $\operatorname{PrP}^{\mathrm{c}}$ on two adjacent cells. In co-cultures of PrP $\mathrm{P}^{\mathrm{c}-}$ expressing brain endothelial cells (WT) and $\operatorname{PrP}^{\mathrm{c}} \mathrm{KO}$ cells, $\mathrm{PrP}^{\mathrm{c}}$ was expressed only between adjacent WT cells, suggesting that this protein is involved in homotypic interactions and contributes to intercellular adhesion by that mechanism [9].

In this study, we examined the effect of neuroinflammation on cell-associated $\operatorname{PrP}^{\mathrm{c}}$ in the context of HIV infection of the CNS. HIV enters the CNS and induces neuroinflammation, BBB dysfunction, and production of toxic factors that can collectively lead to neuronal injury $[62,63]$. This process results in neurocognitive impairment in $40-60 \%$ of HIV-infected individuals, despite antiretroviral therapy $[64,65]$. Adhesion molecules such as $\operatorname{PrP}^{\mathrm{c}}$ are expressed on cells of the CNS and the BBB, as well as infiltrating leukocytes, and regulate CNS homeostasis. They act as membrane receptors, transduce intracellular signals, and promote cellular communication and adhesion [66, 67]. During HIV infection of the brain, adhesion molecule expression is dysregulated and many physiological processes regulated by these proteins are disrupted, contributing to CNS pathology [68-70].

Previously, we showed that, shed $\left(\mathrm{sPrP}^{\mathrm{c}}\right)$ is increased specifically in the cerebrospinal fluid (CSF) of HIV-positive people with cognitive impairment as compared with HIV- 
A

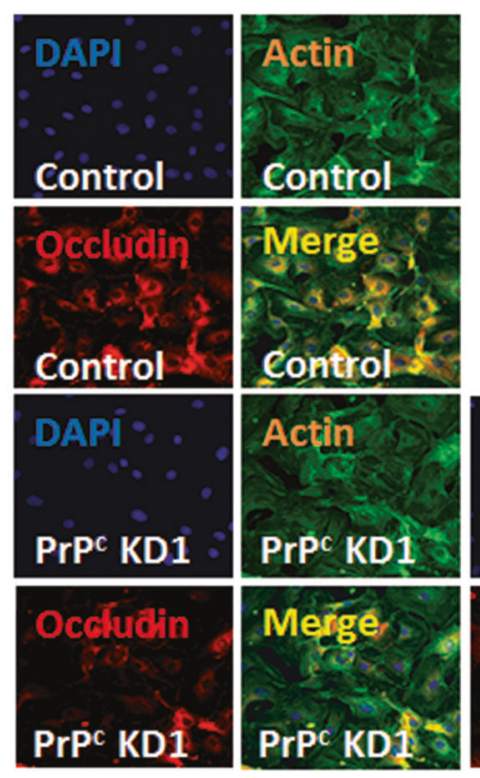

C
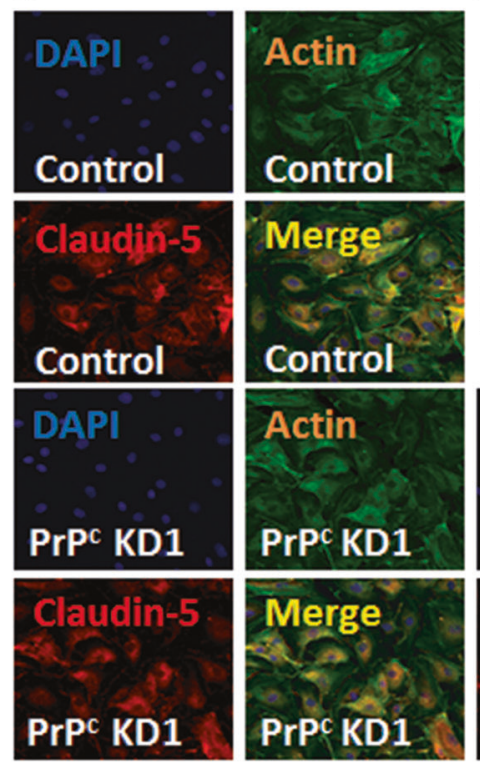

B

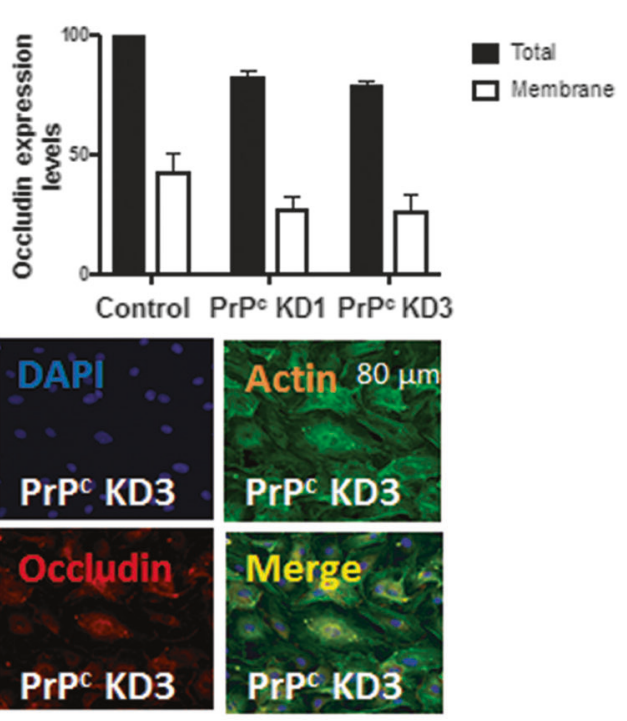

D

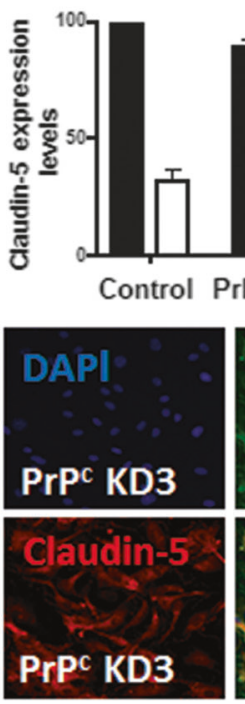

$\operatorname{PrPC}$ KD3
Fig. $6 \operatorname{PrP}^{\mathrm{c}}$ knockdown downregulates total and membrane-associated expression of occludin and claudin-5. Occludin and claudin-5 expression was measured by confocal microscopy and analyzed. Control and $\operatorname{PrP}^{\mathrm{c}}$ knockdown cells were plated on ibdi dishes and fixed with PFA. Cells were stained using occludin and claudin-5 antibodies and analyzed for changes in expression and localization. a Cells were stained with DAPI to identify cell nuclei and labeled with phalloidin to identify the shape of the cells. $\operatorname{PrP}^{\mathrm{c}} \mathrm{KD} 1$ and $\operatorname{PrP}^{\mathrm{c}} \mathrm{KD} 3$ show reduced total occludin and cell membrane occludin. b To compare conditions, similar number of cells (300-800 cells) and total area was analyzed. Control cells had $43 \%$ of their total occludin as membrane protein. $\operatorname{PrP}^{\mathrm{c}} \mathrm{KD} 1$ had reduced membrane occludin $(28 \%)$, whereas $\operatorname{PrP}^{\mathrm{c}} \mathrm{KD} 3$ had $27 \%$ of their total occludin as membrane occludin. c Cells were

positive people with no cognitive impairment [71]. This increase in $\mathrm{SPrP}^{\mathrm{c}}$ correlated with CSF CCL2 levels, indicating that $\operatorname{PrP}^{\mathrm{c}}$ shedding is increased during stained with DAPI to identify cell nuclei and labeled with phalloidin to identify the shape of the cells. $\operatorname{PrP}^{\mathrm{c}} \mathrm{KD} 1$ and $\operatorname{PrP}^{\mathrm{c}} \mathrm{KD} 3$ show reduced total claudin-5 and cell membrane claudin-5. d To compare conditions, similar number of cells (300-800 cells) and total area was analyzed. Control cells had $32.64 \%$ of their total claudin-5 as membrane protein. $\operatorname{PrP}^{\mathrm{c}} \mathrm{KD} 1$ had reduced membrane claudin-5 (25\%), whereas $\operatorname{PrP}^{\mathrm{c}} \mathrm{KD} 3$ had $22.65 \%$ of their total claudin-5 as membrane claudin-5. Significance was determined using ANOVA test. $* p \leq 0.001, \# p \leq 0.0002$. We found that TNF- $\alpha$ and VEGF decrease surface $\operatorname{PrP}^{\mathrm{c}}$, an adhesion protein, from human brain microvascular endothelial cells, a major component of the blood-brain barrier. We also showed that loss of $\operatorname{PrP}^{\mathrm{c}}$ results in decreased tight junction proteins claudin- 5 and occludin and increased permeability of the endothelial layer

neuroinflammation. In addition, we also demonstrated that $\mathrm{PrP}^{\mathrm{c}}$ shedding from cultured human astrocytes is increased in the presence of inflammatory factors CCL2 and TNF- $\alpha$. 
We characterized the mechanism by which $\operatorname{PrP}^{\mathrm{c}}$ is cleaved, which is by the A disintegrin and metalloproteinase domain-containing protein 10 (ADAM10) [72]. Shed $\operatorname{PrP}^{\mathrm{c}}$, in turn, increased the release of cytokines and chemokines from astrocytes, whereas decreased glutamate uptake [72], suggesting an additional mechanism by which shed $\operatorname{PrP}^{\mathrm{c}}$ may play a role in neuroinflammation.

In cerebellar granule cells, $\operatorname{PrP}^{c}$ has been shown to be localized in lipid rafts in a specific detergent-resistant domain known as Prion domain [73, 74]. These cholesterol and sphingolipid-enriched areas of the cell membrane are suggested to be important to stabilize $\operatorname{PrP}^{\mathrm{c}}$ in its native $(\alpha-$ helical) conformation but do not seem to affect its cleavage [75]. In addition, the conversion of $\operatorname{PrP}^{\mathrm{c}}$ to the scrapie form $\left(\mathrm{PrP}^{\mathrm{sc}}\right)$ seems to occur in lipid rafts [75]. Studies implicate ADAM10 and ADAM17 in the shedding of $\operatorname{PrP}^{\mathrm{c}}$ in the brain and specifically from neurons [76]. However, no studies have been conducted in astrocytes to study the role of lipid rafts in cleavage or conformational stability of $\operatorname{PrP}^{\mathrm{c}}$.

In this current study, we examined the effect of inflammation on BMVEC cell surface $\operatorname{PrP}^{\mathrm{c}}$ expression by treating cells with TNF- $\alpha$ and VEGF, and identifying potential consequences of changes in this expression. TNF- $\alpha$ and VEGF are increased during neuroinflammation and have been shown to decrease BBB integrity [31, 39, 46, 47]. We found that both TNF- $\alpha$ and VEGF decrease surface $\operatorname{PrP}^{\mathrm{c}}$. To determine the mechanisms for this decrease, we examined changes in $\operatorname{PrP}^{\mathrm{c}}$ protein and mRNA expression in response to these inflammatory factors. Both TNF- $\alpha$ and VEGF decrease $\mathrm{PrP}^{\mathrm{c}}$ total protein in BMVEC as well as PRNP expression, suggesting that these factors regulate the de novo synthesis of $\mathrm{PrP}^{\mathrm{c}}$.

In our experiments we used TNF- $\alpha$ at $10 \mathrm{ng} / \mathrm{ml}$, which is the concentration used in many in vitro studies. This has been shown to elicit responses in cultured cells that often reflect what can be detected in vivo. Although this value is higher than the physiological TNF- $\alpha$ levels of serum, plasma, and tissue, in pathological conditions serum concentrations of TNF- $\alpha$ of up to $50 \mathrm{ng} / \mathrm{ml}$ have been quantified $[77,78]$. Similarly, serum VEGF levels in normal physiological conditions are lower than the concentration used in our study $(100 \mathrm{ng} / \mathrm{ml})$. However, serum VEGF values as high as $1208 \mathrm{ng} / \mathrm{ml}$ have been shown in pathological states [79].

Previously PRNP, the gene encoding $\operatorname{PrP}^{\mathrm{c}}$, was thought to be a housekeeping gene because of the absence of a TATA box. However, later evidence showed that this gene has binding sites for several transcription factors including NFAT, AP1, AP2, MEF2, and p53, indicating that $\operatorname{PrP}^{\mathrm{c}}$ expression may be regulated by various cellular factors [80-83]. In human neuroblastoma cells, TNF- $\alpha$ and IL- $\beta$ cause increased $\mathrm{PrP}^{\mathrm{c}}$ transcripts, whereas IFN- $\gamma$ decreased $\mathrm{PrP}^{\mathrm{c}}$ mRNA [84]. In addition to cytokines, heat shock and oxidative stress have also been shown to increase $\operatorname{PrP}^{\mathrm{c}}$ expression [85, 86].

The role of cell-associated $\operatorname{PrP}^{\mathrm{c}}$ in intercellular adhesion and changes in the expression of this protein in response to inflammation have also been studied in other diseases such as irritable bowel syndrome [26]. In intestinal epithelium $\mathrm{PrP}^{\mathrm{c}}$ localizes to cell junctions and in colonic epithelium of individuals with Crohn's disease and ulcerative colitis, hypothesized to be caused, in part, by disrupted barriers, levels of $\operatorname{PrP}^{\mathrm{c}}$ at cell junctions were decreased. These results suggest that $\operatorname{PrP}^{c}$ is essential for barrier integrity and function of the intestine [26].

Although the presence of $\operatorname{PrP}^{\mathrm{c}}$ at endothelial cell junctions was shown, its specific contribution to BMVEC monolayer integrity has not been determined. In the present study, we used lentivirus shRNA delivery to knockdown $\mathrm{PrP}^{\mathrm{c}}$ in BMVEC and examined the effect of $\mathrm{PrP}^{\mathrm{c}}$ loss on endothelial monolayer permeability. We found that cell lines that had low level surface $\operatorname{PrP}^{\mathrm{c}}$ formed monolayers that exhibited increased permeability as determined by a FITCdextran permeability assay. In human Caco-2/TC7 enterocytes, $\operatorname{PrP}^{\mathrm{c}}$ silencing led to decreased barrier properties of this cell type by changing the localization and expression of junctional and adhesion proteins E-cadherin, claudin-5, and occludin [26]. One potential mechanism by which $\operatorname{PrP}^{c}$ knockdown increases BMVEC monolayer permeability is by changing the distribution and expression of tight junction and adhesion proteins. Both VEGF and TNF- $\alpha$ downregulate $\mathrm{TJ}$ proteins claudin-5, and occludin and increase endothelial barrier permeability [39, 46, 47]. In this study, we showed that VEGF and TNF- $\alpha$ decrease $\operatorname{PrP}^{c}$ on $\mathrm{BMVEC}$ and that the absence of $\operatorname{PrP}^{\mathrm{c}}$ from these cells increases endothelial monolayer permeability. We propose that the downregulation of $\operatorname{PrP}^{\mathrm{c}}$ induced by VEGF and TNF- $\alpha$ will contribute directly to changes in TJ proteins affecting endothelial monolayer integrity.

Interestingly, in our studies, we found that only nearly complete knockdown of $\operatorname{PrP}^{\mathrm{c}}$ has an effect on the permeability of endothelial monolayers. These results suggest that during partial knockdown of this protein, the function of $\operatorname{PrP}^{c}$ might be compensated by another redundant protein, possibly an adhesion or junction protein. However, when $\operatorname{PrP}^{\mathrm{c}}$ is completely absent, this compensatory mechanism might not be enough to compensate for the functional role of $\mathrm{PrP}^{\mathrm{c}}$ in barrier impermeability. Another possible mechanism is that there is excess $\operatorname{PrP}^{\mathrm{c}}$ on the cell surface and the amount of $\operatorname{PrP}^{\mathrm{c}}$ in cell lines that showed partial knockdown may be enough to maintain barrier integrity.

In intestinal epithelium, $\operatorname{PrP}^{c}$ is important in maintaining the intestinal barrier by activating Src- signaling and regulating expression of $\mathrm{TJ}$ and $\mathrm{AJ}$ proteins including occludin, ZO-1, and E-cadherin [26]. In epithelial cell lines including A431, MCF7, and Hela cells, $\operatorname{PrP}^{\mathrm{c}}$ regulates expression of 
E-Cadherin and B-catenin through a reggie-1 and EGF-Rmediated pathway affecting cell-cell adhesion [7]. However, in BMVEC, AJ or TJ proteins that are regulated by $\mathrm{PrP}^{\mathrm{c}}$, or signaling molecules that are activated or modulated by this protein to affect endothelial barrier integrity have not yet been determined. Therefore, we examined whether knockdown of surface $\operatorname{PrP}^{\mathrm{c}}$ affects the expression and distribution of $\mathrm{TJ}$ proteins that will contribute to a more permeable barrier. We found that $\operatorname{PrP}^{\mathrm{c}}$ knockdown results in decreased expression of occludin and claudin-5. As $\operatorname{PrP}^{\mathrm{c}}$ is not a transmembrane protein, it is possible that it causes these changes in expression of proteins that are essential for membrane integrity by coupling with other adaptor proteins. In this study, we examined the effect of $\operatorname{PrP}^{\mathrm{c}}$ loss on the expression and localization of occludin and claudin-5. However, as both TNF- $\alpha$ and VEGF regulate the expression of ZO-1 [39, 87], we plan on expanding our studies to include the effects of $\mathrm{PrP}^{\mathrm{c}}$ loss on the regulation of $\mathrm{ZO}-1$ expression.

An intact BBB is essential for maintaining brain homeostasis and highly selective endothelial permeability, and its impairment has been shown to lead to neuroinflammation. $\mathrm{TJ}$ and $\mathrm{AJ}$ molecules, including claudin-5, occludin, and $\mathrm{PrP}^{\mathrm{c}}$, are essential for regulating endothelial permeability. Thus, proper localization and expression of these proteins are critical for BBB integrity [19, 20, 22, 23]. Our study shows that TNF- $\alpha$ and VEGF, factors associated with BBB disruption, decrease $\operatorname{PrP}^{\mathrm{c}}$ in BMVEC. $\operatorname{PrP}^{\mathrm{c}}$ on the cell surface of BMVEC is essential for monolayer integrity and its loss increases permeability. $\operatorname{PrP}^{\mathrm{c}}$ also regulates the expression and localization of TJ proteins claudin-5 and occludin, which are important in maintaining a proper barrier. Therefore, a possible mechanism by which TNF- $\alpha$ and VEGF increase BBB permeability is by downregulating $\mathrm{PrP}^{\mathrm{c}}$, which in turn will affect $\mathrm{TJ}$ protein expression and localization. This may result in imbalance of ions and transmitters, less-efficient prevention of toxin and pathogen infiltration, as well as increased leukocyte diapedesis across the barrier, which can subsequently lead to neuroinflammation [88]. In an in vivo setting, a complex interaction of several cell types including astrocytes, microglia and macrophages leads to the neuropathogenesis that is subsequent to HIV infection of the CNS. Our in vitro system in this study enables us to elucidate individual mechanisms, which lead to transient permeability of the endothelial layer and BBB integrity loss. Future studies will examine the effect of inflammation on BBB permeability and cognitive function in $\operatorname{PrP}^{\mathrm{c}}$ knockout mice in the context of HIV infection.

Acknowledgements We thank Dr. Tina M. Calderon, Dr. LoretoTorres Carvallo, Dr. Mike Veenstra, Dr. Matias Jaureguiberry, and Lillie Lopez for their valuable contributions to this project. We also thank the shRNA Core and the Flow Cytometry Core at Albert Einstein College of Medicine. This work was supported by U.S. National Institutes of Health Grants R01MH075679 (to JWB); R01DA02556704 (to JWB); R21MH102113-01A1 (to JWB); R01MH090958 (to JWB and BWM); R01MH07754208 (to JWB and BWM); MH096625 and PHRI Funding (to EAE).

Conflict of interest The authors declare no conflict of interest.

\section{References}

1. Watts JC, Bourkas MEC, Arshad H. The function of the cellular prion protein in health and disease. Acta Neuropathol. 2018;135:159-78.

2. Sarnataro D, Pepe A, Zurzolo C. Cell biology of prion protein. Prog Mol Biol Transl Sci. 2017;150:57-82.

3. Wulf MA, Senatore A, Aguzzi A. The biological function of the cellular prion protein: an update. BMC Biol. 2017;15:34.

4. Linden R. The biological function of the prion protein: a cell surface scaffold of signaling modules. Front Mol Neurosci. 2017;10:77.

5. Castle AR, Gill AC. Physiological functions of the cellular prion protein. Front Mol Biosci. 2017;4:19.

6. Hirsch TZ, Hernandez-Rapp J, Martin-Lannerée S, et al. PrP C signalling in neurons: from basics to clinical challenges. Biochimie. 2014;104:2-11.

7. Petit CS, Besnier L, Morel E, et al. Roles of the cellular prion protein in the regulation of cell-cell junctions and barrier function. Tissue Barriers. 2013;1:e24377.

8. Jeon JW, Park BC, Jung JG, et al. The soluble form of the cellular prion protein enhances phagocytic activity and cytokine production by human monocytes via activation of ERK and NF-kappaB. Immune Netw. 2013;13:148-56.

9. Viegas P, Chaverot N, Enslen H, et al. Junctional expression of the prion protein PrPC by brain endothelial cells: a role in transendothelial migration of human monocytes. J Cell Sci. 2006; 119:4634-43.

10. Rousset M, Leturque A, Thenet $\mathrm{S}$. The nucleo-junctional interplay of the cellular prion protein: a new partner in cancer-related signaling pathways? Prion. 2016;10:143-52.

11. Lewis V, Hooper NM. The role of lipid rafts in prion protein biology. Front Biosci. 2010;16:151-68.

12. Sarnataro D, Campana V, Paladino S, et al. PrPC association with lipid rafts in the early secretory pathway stabilizes its cellular conformation. Mol Biol Cell. 2004;15:4031-42.

13. Mattei V, Garofalo T, Misasi R, et al. Association of cellular prion protein with gangliosides in plasma membrane microdomains of neural and lymphocytic cells. Neurochem Res. 2002;27:743-9.

14. Rudd PM, Merry AH, Wormald MR, et al. Glycosylation and prion protein. Curr Opin Struct Biol. 2002;12:578-86.

15. Rudd PM, Wormald MR, Wing DR, et al. Prion glycoprotein: structure, dynamics, and roles for the sugars. Biochemistry. 2001;40:3759-66.

16. Lima FR, Arantes CP, Muras AG, et al. Cellular prion protein expression in astrocytes modulates neuronal survival and differentiation. J Neurochem. 2007;103:2164-76.

17. Brown DR, Besinger A, Herms JW, et al. Microglial expression of the prion protein. Neuroreport. 1998;9:1425-9.

18. Richardson DD, Tol S, Valle-Encinas E, et al. The prion protein inhibits monocytic cell migration by stimulating beta1 integrin adhesion and uropod formation. J Cell Sci. 2015;128:3018-29.

19. Zlokovic BV. The blood-brain barrier in health and chronic neurodegenerative disorders. Neuron. 2008;57:178-201. 
20. Abbott NJ, Rönnbäck L, Hansson E. Astrocyte-endothelial interactions at the blood-brain barrier. Nat Rev Neurosci. 2006;7:41-53.

21. Bazzoni G, Dejana E. Endothelial cell-to-cell junctions: molecular organization and role in vascular homeostasis. Physiol Rev. 2004;84:869-901.

22. Theodorakis PE, Muller EA, Craster RV, et al. Physical insights into the blood-brain barrier translocation mechanisms. Phys Biol. 2017;14:041001.

23. Begley DJ, Brightman MW. Structural and functional aspects of the blood-brain barrier. Prog Drug Res. 2003;61:39-78.

24. Stamatovic SM, Keep RF, Wang MM, et al. Caveolae-mediated internalization of occludin and claudin-5 during CCL2-induced tight junction remodeling in brain endothelial cells. J Biol Chem. 2009;284:19053-66.

25. Schenk GJ, de Vries HE. Altered blood-brain barrier transport in neuro-inflammatory disorders. Drug Discov Today Technol. 2016;20:5-11.

26. Petit CS, Barreau F, Besnier L, et al. Requirement of cellular prion protein for intestinal barrier function and mislocalization in patients with inflammatory bowel disease. Gastroenterology. 2012;143:122-32. e115

27. Pan W, Kastin AJ. Tumor necrosis factor and stroke: role of the blood-brain barrier. Prog Neurobiol. 2007;83:363-74.

28. Lv S, Song HL, Zhou Y, et al. Tumour necrosis factor- $\alpha$ affects blood-brain barrier permeability and tight junction-associated occludin in acute liver failure. Liver Int. 2010;30:1198-210.

29. Friedl J, Puhlmann M, Bartlett DL, et al. Induction of permeability across endothelial cell monolayers by tumor necrosis factor (TNF) occurs via a tissue factor-dependent mechanism: relationship between the procoagulant and permeability effects of TNF. Blood. 2002;100:1334-9.

30. Scutari R, Alteri C, Perno CF et al. The Role of HIV Infection in Neurologic Injury. Brain Sci 2017;7:pii: E38.

31. Montgomery SL, Bowers WJ. Tumor necrosis factor-alpha and the roles it plays in homeostatic and degenerative processes within the central nervous system. J Neuroimmune Pharmacol. 2012;7:42-59.

32. John CC, Panoskaltsis-Mortari A, Opoka RO, et al. Cerebrospinal fluid cytokine levels and cognitive impairment in cerebral malaria. Am J Trop Med Hyg. 2008;78:198-205.

33. Persidsky Y, Buttini M, Limoges J, et al. An analysis of HIV-1associated inflammatory products in brain tissue of humans and SCID mice with HIV-1 encephalitis. J Neurovirol. 1997;3:401-16.

34. Feuerstein G, Liu T. Barone F. Cytokines, inflammation, and brain injury: role of tumor necrosis factor-alpha. Cerebrovasc Brain Metab Rev. 1993;6:341-60.

35. Tyor WR, Glass JD, Griffin JW, et al. Cytokine expression in the brain during the acquired immunodeficiency syndrome. Ann Neurol. 1992;31:349-60.

36. Benveniste EN, Sparacio SM, Norris JG, et al. Induction and regulation of interleukin-6 gene expression in rat astrocytes. J Neuroimmunol. 1990;30:201-12.

37. Eugenin EA, Osiecki K, Lopez L, et al. CCL2/monocyte chemoattractant protein-1 mediates enhanced transmigration of human immunodeficiency virus (HIV)-infected leukocytes across the blood-brain barrier: a potential mechanism of HIV-CNS invasion and NeuroAIDS. J Neurosci. 2006;26:1098-106.

38. Ehrlich LC, Hu S, Sheng WS, et al. Cytokine regulation of human microglial cell IL-8 production. J Immunol. 1998;160:1944-8.

39. Aveleira CA, Lin C-M, Abcouwer SF, et al. TNF- $\alpha$ signals through $\mathrm{PKC} / \mathrm{NF}-\mathrm{KB}$ to alter the tight junction complex and increase retinal endothelial cell permeability. Diabetes. 2010;59:2872-82.
40. Dobrogowska D, Lossinsky A, Tarnawski M, et al. Increased blood-brain barrier permeability and endothelial abnormalities induced by vascular endothelial growth factor. J Neurocytol. 1998;27:163-73.

41. Proescholdt MA, Jacobson S, Tresser N, et al. Vascular endothelial growth factor is expressed in multiple sclerosis plaques and can induce inflammatory lesions in experimental allergic encephalomyelitis rats. J Neuropathol Exp Neurol. 2002;61:914-25.

42. Greenberg DA, Jin K. From angiogenesis to neuropathology. Nature. 2005;438:954-9.

43. Jin KL, Mao XO, Greenberg DA. Vascular endothelial growth factor: direct neuroprotective effect in in vitro ischemia. Proc Natl Acad Sci USA. 2000;97:10242-7.

44. Storkebaum E, Lambrechts D, Dewerchin M, et al. Treatment of motoneuron degeneration by intracerebroventricular delivery of VEGF in a rat model of ALS. Nat Neurosci. 2005;8:85-92.

45. Lange C, Storkebaum E, de Almodovar CR, et al. Vascular endothelial growth factor: a neurovascular target in neurological diseases. Nat Rev Neurol. 2016;12:439-54.

46. Argaw AT, Gurfein BT, Zhang Y, et al. VEGF-mediated disruption of endothelial CLN-5 promotes blood-brain barrier breakdown. Proc Natl Acad Sci USA. 2009;106:1977-82.

47. Argaw AT, Zhang Y, Snyder BJ, et al. IL- $1 \beta$ regulates blood-brain barrier permeability via reactivation of the hypoxia-angiogenesis program. J Immunol. 2006;177:5574-84.

48. Esser S, Lampugnani MG, Corada M, et al. Vascular endothelial growth factor induces VE-cadherin tyrosine phosphorylation in endothelial cells. J Cell Sci. 1998;111:1853-65.

49. Gavard J, Gutkind JS. VEGF controls endothelial-cell permeability by promoting the $\beta$-arrestin-dependent endocytosis of VEcadherin. Nat Cell Biol. 2006;8:1223-34

50. Grant I, Atkinson JH, Hesselink JR, et al. Evidence for early central nervous system involvement in the acquired immunodeficiency syndrome (AIDS) and other human immunodeficiency virus (HIV) infections: Studies with neuropsychologic testing and magnetic resonance imaging. Ann Int Med. 1987;107:828-36.

51. Price RW, Brew B, Sidtis J, et al. The brain in AIDS: central nervous system HIV-1 infection and AIDS dementia complex. Science. 1988;239:586-92.

52. Ton H, Xiong H. Astrocyte dysfunctions and HIV-1 neurotoxicity. J AIDS Clin Res. 2013;4:255.

53. Ansaloni S, Lelkes N, Snyder J, et al. A streamlined sub-cloning procedure to transfer shRNA from a pSM2 vector to a pGIPZ lentiviral vector. J RNAi Gene Silencing. 2010;6:411-5.

54. Kaul M, Garden GA, Lipton SA. Pathways to neuronal injury and apoptosis in HIV-associated dementia. Nature. 2001;410:988-94.

55. Saha RN, Pahan K. Tumor necrosis factor- $\alpha$ at the crossroads of neuronal life and death during HIV-associated dementia. J Neurochem. 2003;86:1057-71.

56. Eugenin EA, Berman JW. Chemokine-dependent mechanisms of leukocyte trafficking across a model of the blood-brain barrier. Methods. 2003;29:351-61.

57. Eugenin EA, Clements JE, Zink MC, et al. Human immunodeficiency virus infection of human astrocytes disrupts blood-brain barrier integrity by a gap junction-dependent mechanism. J Neurosci. 2011;31:9456-65.

58. Ballabh P, Braun A, Nedergaard M. The blood-brain barrier: an overview: structure, regulation, and clinical implications. Neurobiol Dis. 2004;16:1-13.

59. Hawkins BT, Davis TP. The blood-brain barrier/neurovascular unit in health and disease. Pharmacol Rev. 2005;57:173-85.

60. Luissint A-C, Artus C, Glacial F, et al. Tight junctions at the blood-brain barrier: physiological architecture and diseaseassociated dysregulation. Fluids Barriers CNS. 2012;9:1-12. 
61. Morel E, Fouquet S, Chateau D, et al. The cellular prion protein $\mathrm{PrPc}$ is expressed in human enterocytes in cell-cell junctional domains. J Biol Chem. 2004;279:1499-505.

62. Saylor D, Dickens AM, Sacktor N, et al. HIV-associated neurocognitive disorder--pathogenesis and prospects for treatment. Nat Rev Neurol. 2016;12:234-48.

63. Spudich S, Gonzalez-Scarano F. HIV-1-related central nervous system disease: current issues in pathogenesis, diagnosis, and treatment. Cold Spring Harb Perspect Med. 2012;2: a007120.

64. Chan P, Hellmuth J, Spudich S, et al. Cognitive impairment and persistent CNS injury in treated HIV. Curr HIV/AIDS Rep. 2016;13:209-17.

65. Heaton RK, Clifford DB, Franklin DR Jr., et al. HIV-associated neurocognitive disorders persist in the era of potent antiretroviral therapy: CHARTER Study. Neurology. 2010;75:2087-96.

66. Dietrich J-B. The adhesion molecule ICAM-1 and its regulation in relation with the blood-brain barrier. J Neuroimmunol. 2002;128:58-68.

67. Aplin AE, Howe AK, Juliano R. Cell adhesion molecules, signal transduction and cell growth. Curr Opin Cell Biol. 1999;11:737-44.

68. Williams DW, Eugenin EA, Calderon TM, et al. Monocyte maturation, HIV susceptibility, and transmigration across the blood-brain barrier are critical in HIV neuropathogenesis. J Leukoc Biol. 2012;91:401-15.

69. Huang W, Eum SY, Andras IE, et al. PPARalpha and PPARgamma attenuate HIV-induced dysregulation of tight junction proteins by modulations of matrix metalloproteinase and proteasome activities. FASEB J. 2009;23:1596-606.

70. Seilhean D, Dzia-Lepfoundzou A, Sazdovitch V, et al. Astrocytic adhesion molecules are increased in HIV-1-associated cognitive/motor complex. Neuropathol Appl Neurobiol. 1997;23:83-92.

71. Roberts TK, Eugenin EA, Morgello S, et al. PrP C, the cellular isoform of the human prion protein, is a novel biomarker of HIVassociated neurocognitive impairment and mediates neuroinflammation. Am J Pathol. 2010;177:1848-60.

72. Megra BW, Eugenin EA, Berman JW. The role of shed $\operatorname{PrP}(\mathrm{c})$ in the neuropathogenesis of HIV infection. J Immunol. 2017;199:224-32.

73. Botto L, Masserini M, Cassetti A, et al. Immunoseparation of Prion protein-enriched domains from other detergent-resistant membrane fractions, isolated from neuronal cells. FEBS Lett. 2004;557:143-7.
74. Farina F, Botto L, Chinello C, et al. Characterization of prion protein-enriched domains, isolated from rat cerebellar granule cells in culture. J Neurochem. 2009;110:1038-48.

75. Botto L, Cunati D, Coco S, et al. Role of lipid rafts and GM1 in the segregation and processing of prion protein. PLoS ONE. 2014;9:e98344.

76. Linsenmeier L, Altmeppen HC, Wetzel S, et al. Diverse functions of the prion protein - does proteolytic processing hold the key? Biochim Biophys Acta. 2017;1864:2128-37.

77. Andrade Junior DR, Santos SA, Castro I, et al. Correlation between serum tumor necrosis factor alpha levels and clinical severity of tuberculosis. Braz J Infect Dis. 2008;12:226-33.

78. Damas P, Reuter A, Gysen P, et al. Tumor necrosis factor and interleukin-1 serum levels during severe sepsis in humans. Crit Care Med. 1989;17:975-8.

79. Di Raimondo F, Azzaro MP, Palumbo GA, et al. Elevated vascular endothelial growth factor (VEGF) serum levels in idiopathic myelofibrosis. Leukemia. 2001;15:976-80.

80. Inoue $\mathrm{S}$, Tanaka $\mathrm{M}$, Horiuchi $\mathrm{M}$, et al. Characterization of the bovine prion protein gene: the expression requires interaction between the promoter and intron. J Vet Med Sci. 1997;59:175-83.

81. Mahal SP, Asante EA, Antoniou M, et al. Isolation and functional characterisation of the promoter region of the human prion protein gene. Gene. 2001;268:105-14.

82. Varela-Nallar L, Toledo EM, Larrondo LF, et al. Induction of cellular prion protein gene expression by copper in neurons. Am J Physiol Cell Physiol. 2006;290:C271-81.

83. Sander P, Hamann H, Drögemüller C, et al. Bovine prion protein gene (PRNP) promoter polymorphisms modulate PRNP expression and may be responsible for differences in bovine spongiform encephalopathy susceptibility. J Biol Chem. 2005;280:37408-14.

84. Satoh J-i, Kurohara K, Yukitake $\mathrm{M}$, et al. Constitutive and cytokine-inducible expression of prion protein gene in human neural cell lines. J Neuropathol Exp Neurol. 1998;57:131-9.

85. Sauer H, Wefer K, Vetrugno V, et al. Regulation of intrinsic prion protein by growth factors and TNF-alpha: the role of intracellular reactive oxygen species. Free Radic Biol Med. 2003;35:586-94.

86. Shyu WC, Harn HJ, Saeki K, et al. Molecular modulation of expression of prion protein by heat shock. Mol Neurobiol. 2002;26:1-12.

87. Sandoval KE, Witt KA. Blood-brain barrier tight junction permeability and ischemic stroke. Neurobiol Dis. 2008;32:200-19.

88. Obermeier B, Daneman R, Ransohoff RM. Development, maintenance and disruption of the blood-brain barrier. Nat Med. 2013;19:1584-96. 